\title{
A Novel Homozygous Frameshift WDR81 Mutation associated with Microlissencephaly, Corpus Callosum Agenesis, and Pontocerebellar Hypoplasia
}

\author{
Tibor Kalmár ${ }^{1, *}$ Katalin Szakszon ${ }^{2, *}$ Zoltán Maróti ${ }^{1} \quad$ Alíz Zimmermann ${ }^{1}$ Adrienn Máté ${ }^{1}$ \\ Melinda Zombor ${ }^{1}$ Csaba Bereczki ${ }^{1}$ László Sztriha10 \\ ${ }^{1}$ Department of Pediatrics, University of Szeged, Szeged, Hungary \\ 2 Department of Pediatrics, University of Debrecen, Debrecen, Hungary \\ J Pediatr Genet \\ Address for correspondence László Sztriha, MD, PhD, DSc, \\ Department of Pediatrics, Division B, University of Szeged, Temesvári \\ krt. 35-37, 6726 Szeged, Hungary \\ (e-mail: sztriha.laszlo@med.u-szeged.hu).
}

\author{
Abstract \\ Keywords \\ - microlissencephaly \\ - pontocerebellar \\ hypoplasia \\ - WDR81 mutation
}

\section{Introduction}

Microlissencephaly is characterized by severe congenital microcephaly, which is associated with smooth brain surface due to abnormal cortical lamination. ${ }^{1}$ Phenotypic and genotypic heterogeneity of this brain malformation became more evident in the last decades. Till now, several disease-causing genes, such as NDE1, KATNB1, TUBA1A, TUBB2B, TUBB3, CIT, and ACTG1, have been identified. ${ }^{2-6}$ Recently, compound heterozygous mutations in the WDR81 gene have been ascertained in patients with the microcephaly/microlissencephaly-pontocerebellar hypoplasia/atrophy disease spectrum. ${ }^{7,8}$ In the present study, we reported two siblings, a boy and a girl, with complex brain malformation of microlissencephaly, corpus callosum agenesis, and pontocerebellar hypoplasia. In the girl, a novel homozygous pathogenic WDR81 variant was identified. Her brother died before having been tested genetically; however, the phenotypic similarities suggested that he had the same mutation.

\footnotetext{
Tibor Kalmár and Katalin Szakszon contributed equally to this manuscript.
}

received

February 18, 2020

accepted after revision

April 22, 2020

\section{Case Reports}

Patient 1, a boy (-Fig. 1) from the first uneventful pregnancy, was born at the 36th gestational week to nonconsanguineous Caucasian parents. His head circumference was $25 \mathrm{~cm}(-5.2$ standard deviation [SD]), weight 2,080 g ( $-1.5 \mathrm{SD})$, and length $45 \mathrm{~cm}(-0.9 \mathrm{SD})$ at the time of birth. There was no evidence of maternal alcohol and drug abuse, or intrauterine infection. The metabolic workup was normal. Dysmorphic features included sloping forehead, shallow orbits, arched eyebrows, broad nasal root, epicanthi, small nose, anteversion of the nares, prominent upper jaw, and low-set ears. At the age of 10 months his head circumference was $35.5 \mathrm{~cm}(-8.3 \mathrm{SD})$, weight $7,780 \mathrm{~g}(-2.2 \mathrm{SD})$, and length $68.5 \mathrm{~cm}(-2.0 \mathrm{SD})$. He did not acquire any developmental milestones and had spastic quadriplegia. He died at the age of 2 years. Deoxyribonucleic acid (DNA) or tissue samples were unavailable and an autopsy was not performed. On magnetic resonance imaging (MRI) images at the age of 2 weeks, the whole brain was small with a smooth surface, surrounded by an enlarged extracerebral fluid space. The ventricles were deformed and enlarged. The corpus callosum was not recognizable. The brainstem and cerebellum

Copyright $\odot$ by Georg Thieme Verlag KG, DOI https://doi.org/ Stuttgart . New York ISSN 2146-4596. 


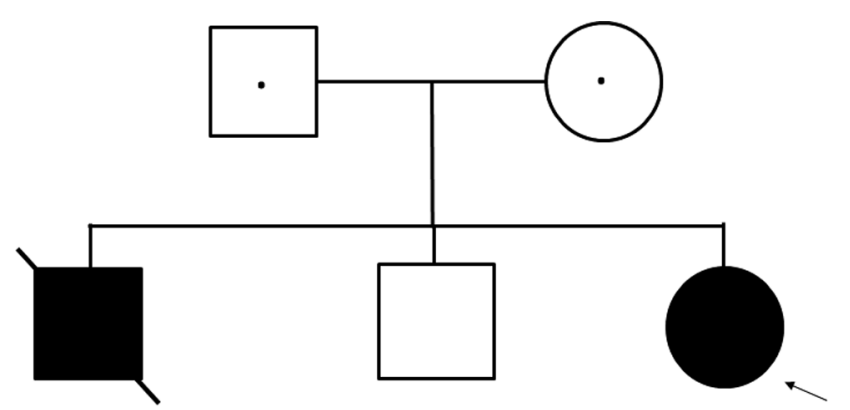

WDR81 NM 001163809.1:c.4668 4669delAG NP_001157281.1:p.Gly1557AspfsTer16

Fig. 1 Pedigree of the family. The WDR81 mutation was segregated in the expected autosomal recessive pattern in all available family members.

were hypoplastic indicating pontocerebellar hypoplasia (-Fig. 2A-C). Other organs were not affected. The parents' second child, a boy, is healthy (-Fig. 1).

Patient 2, a girl ( $\mathbf{- F i g . 1}$ ), was born at term from the third pregnancy after uneventful labor and delivery. At the time of birth, her head circumference was $27 \mathrm{~cm}$ (-5.3 SD), weight $3,000 \mathrm{~g}(-0.8 \mathrm{SD})$, and length $49 \mathrm{~cm}$ (-0.2 SD). She had similar dysmorphic features as Patient 1 . At 3 months of age, her occipitofrontal circumference was $30.5 \mathrm{~cm}(-7.5 \mathrm{SD})$. She did not show any development and had spastic quadriplegia. The MRI images at the age of 6 days revealed similar abnormalities as seen in Patient 1 (-Fig. 2D-F). Other organs were not affected.

Genetic testing was done for Patient 2. Karyotyping was performed by standard protocol, and results showed a normal 46, XX karyotype. Genomic DNA was extracted from peripheral blood samples with the Puregene Kit (Gentra). A homozygous variant in exon 7 of isoform 1 of the WDR81 (NM_001163809.01:c.4668_4669delAG, NP_001157281.1:p. Gly1557AspfsTer16) gene (-Fig. 3A, 3B) was identified by using the Illumina Trusight One Exome Sequencing Panel (Illumina Inc.; San Diego, California, United States), covering the coding region of 4,813 clinically relevant genes. MutationTaster $2^{9}$ indicated that this is a disease-causing mutation. The Genome Aggregation Database describes heterozygous p. Gly1557AspfsTer16 variant [dbSNP(rs771116788)] with allele frequency of 2/278488 (0.000007182). Both heterozygous variants were found in the African population, but clinical data, associated with these mutations, were not reported previously. Patient 2 in this report is the first (and so far the only one) in whom this mutation has been confirmed in homozygous state and whose phenotype is reported. Other databases, such as the Human Gene Mutation Database (HGMD Public) and NHLBI Exome Variant Server, do not
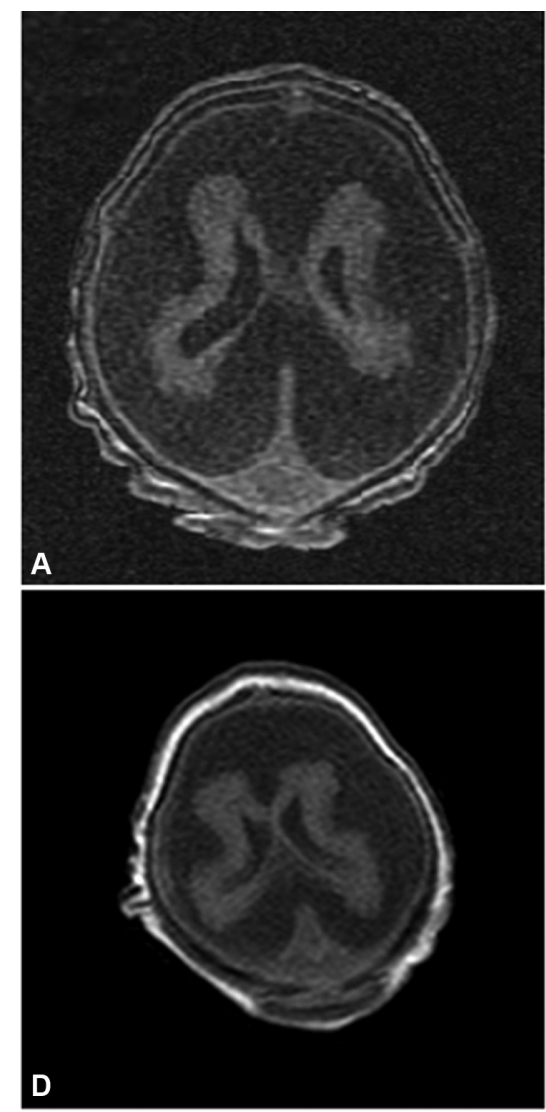
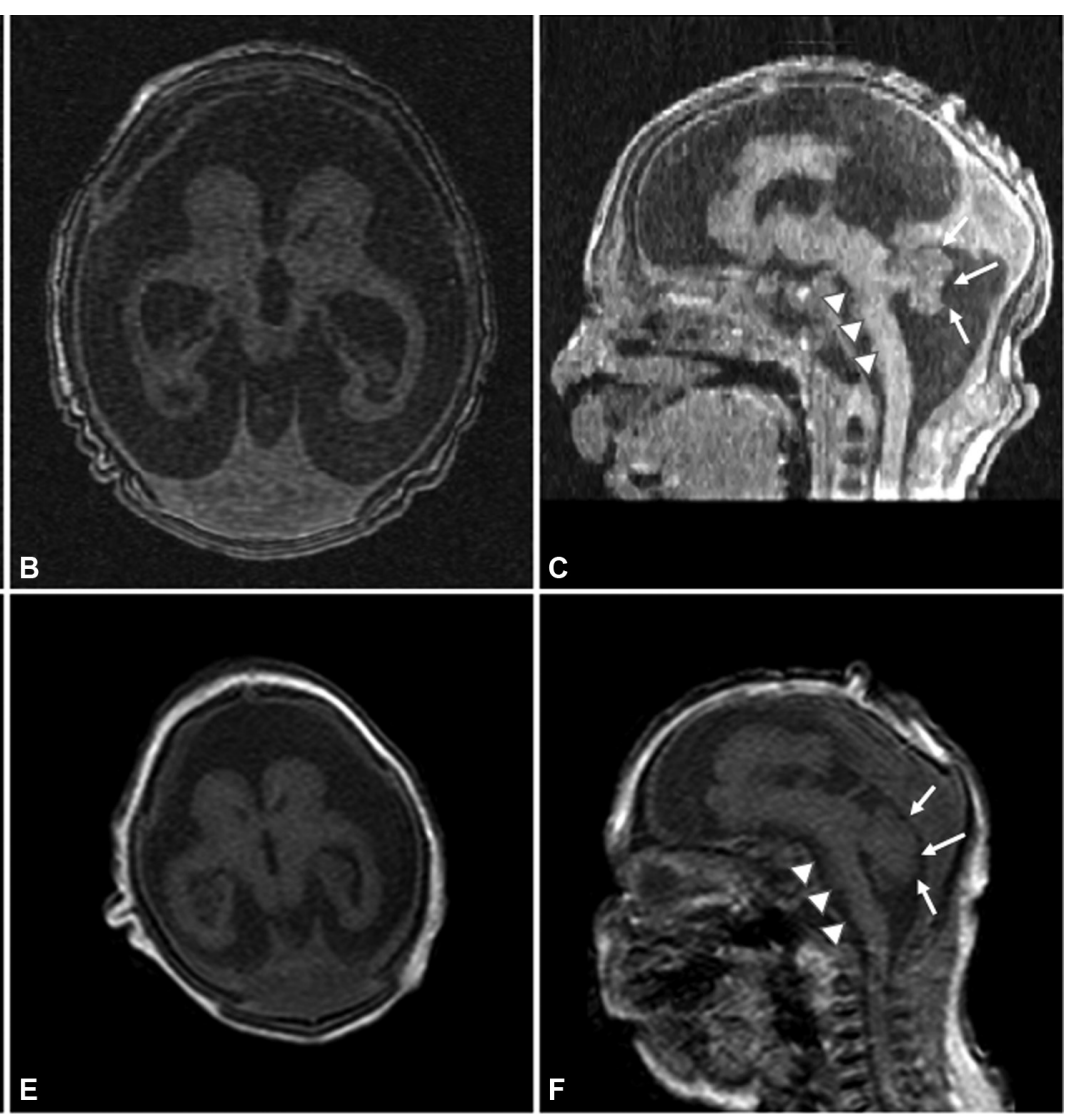

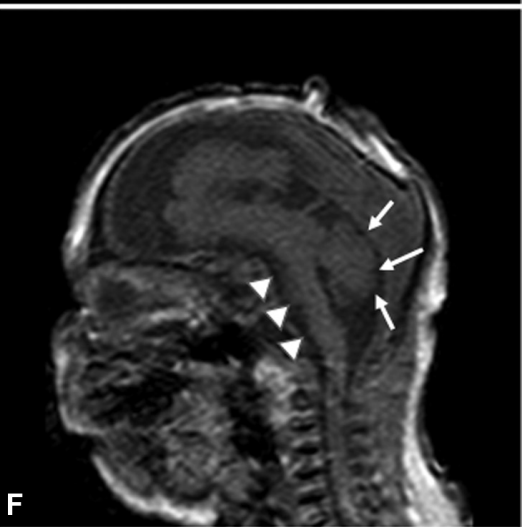

Fig. 2 Brain magnetic resonance imaging (MRI) of the patients. (A-C) Patient 1. T1-weighted axial (A, B) and sagittal (C) MRI images at the age of 2 weeks. The whole brain is extremely small (microbrain) surrounded by an enlarged extra-axial fluid space. The brain mantle is very thin, gray and white matter cannot be distinguished. Complete agyria can be observed. The corpus callosum is absent and the ventricles are dilated. The brainstem (arrowheads) and cerebellum (arrows) are hypoplastic suggesting pontocerebellar hypoplasia. (D-F) Patient 2. T1-weighted axial (D, E) and sagittal (F) MRI images at the age of 6 days. Similar malformation pattern can be seen, as in Patient 1 . 
A

Q1551 D1552 D1553G1554H1555 S1556 G1557 T1558 F1559 G1560

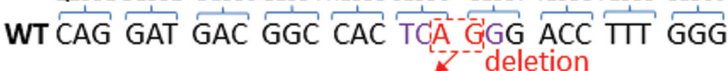

MT CAG GAT GAC GGC CAC TCG GAC CTT TGG GAG Q1551 D1552 D1553 G1554 H1555 S1556 D1557 L1558 W1559 E1560

S1561 V1562 L1563 V1564G1565 N1566 R1567 I1568 Q1569 I1570

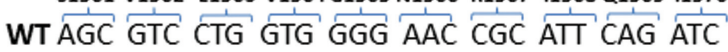

MT CGT CCT GGT GGG GAA CCG CAT TCA GAT CCC R1561 P1562 $\underbrace{\text { G1564 E1565 P1566 }}_{\text {G1563 }} \underbrace{\text { CA1568W1569 E1570 }}_{\text {D1567 }}$

P1571 N1572 D1573 S1574 R1575 P1576 E1577 N1578 P1579G1580

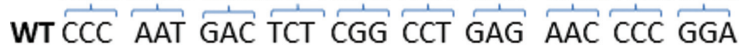

MT CAA TGA Q1571
B
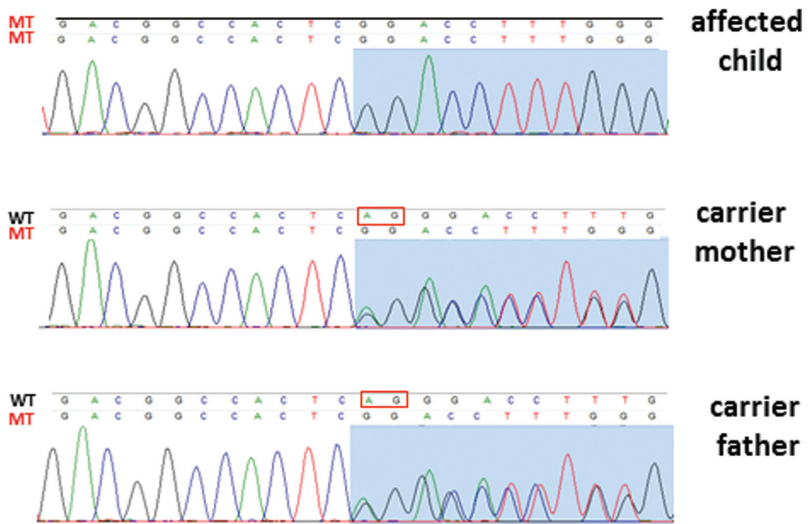

carrier

father

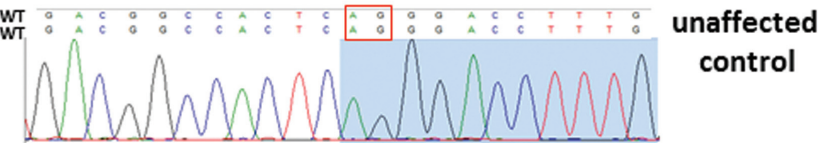

Fig. 3 Molecular testing of the WDR81 gene. (A) The predicted effect of the two-nucleotide deletion in WDR81 shows frameshift and premature STOP codon in the mutant (MT) compared with wild-type (WT) sequence. (B) The presence of the mutation was confirmed by Sanger sequencing in the affected child and her carrier parents. The red box indicates the deleted WT nucleotides AG, while blue highlight marks the sequence positions of the resulting frameshift in the deoxyribonucleic acid (DNA) chromatograms.

contain any data of this mutation and it was also not found in our in-house clinical exome database of 360 unrelated Hungarian persons. Further, Sanger sequencing confirmed the homozygous mutation in the patient and revealed that the parents were heterozygous for this mutation (ClinVar ID: 635849, ClinVar Accession: VCV000635849.1).

\section{Discussion}

Our data suggested a homozygous variant in WDR81 is potentially responsible for the microlissencephaly, corpus callosum agenesis, and pontocerebellar hypoplasia in Patient 2. The same brain malformation was found in her brother (Patient 1) who died without genetic testing. The parents were carriers of this variant.

The WDR81 gene is located on chromosome 17p13.3, consists of 10 exons, and encodes 9 protein isoforms of WD repeat containing protein 81 . The longest isoform 1 consists of 1,941 amino acids and contains an N-terminal BEACH (Beige and Chediak-Higashi) domain, a MFS (major facilitator superfamily) domain, and six C-terminal WD40 repeats (WD40 $\beta$ propeller domain). ${ }^{10}$ It is a transmembrane protein with six membranespinning domains expressed in all tissues, including neurons in all brain regions. ${ }^{10,11}$ In Patient 2, the c.4668_4669delAG mutation caused a frameshift and premature stop codon (p. Gly1557AspfsTer16) in exon 7 of the WDR81 isoform 1 (NM_001163809.01). The mutation may lead either to truncation of the protein with loss of the six C-terminal WD40 repeats and the sixth transmembrane domain (TM6), or nonsensemediated messenger ribonucleic acid decay. ${ }^{7}$

WD40 repeats are a short structural motif of approximately 40 amino acids, often terminating in a tryptophanaspartic acid (W-D) dipeptide. WD40 domain-containing proteins have 4 to 16 repeating units forming a $\beta$-propeller structure. WD40-repeat proteins are implicated in coordinating multiprotein complex assemblies where the repeating units serve as a rigid scaffold for protein interactions. ${ }^{12,13}$ Loss of WD40 repeats may disrupt the interactions of WDR81 protein leading to abnormal network formation.

All the mutations detected so far in WDR81 affected isoform 1 of the protein. ${ }^{7,8,10,14-16}$ Novel compound heterozygous nonsense and missense mutations in WDR81, affecting all domains, have been described recently in association with microcephaly/microlissencephaly, callosal hypoplasia/agenesis, and pontocerebellar hypoplasia/atrophy complex in a few patients (-Table 1). ${ }^{7,8}$ The parents were nonconsanguineous and healthy. WDR81 mutant fibroblasts from the patients showed a significant increase in the mitotic index during prometaphase/metaphase compared with controls, suggesting a delayed prometaphase/metaphase transition. ${ }^{7}$ Further experiments in Drosophila confirmed that the partial knockdown of the fly orthologue of WDR81 resulted in an increased mitotic index in the neuroblasts form of the central brain, with an increase in the proportion of mitotic cells in prometaphase/ metaphase and a decrease in anaphase/telophase, suggesting a delay in the mitotic progression. These mitotic defects may lead to reduced neurogenic cell divisions, alterations of neural cell fates, or to a failure to maintain the progenitor cell population. ${ }^{7}$

Homozygous WDR81 variants in association with fatal congenital hydranencephaly/hydrocephalus have been reported in consanguineous families (- Table 2, Patients 2-4). ${ }^{14,15,17}$ Another phenotype with intellectual disability, cerebellar hypoplasia/atrophy, with or without quadrupedal locomotion due to truncal ataxia (disequilibrium syndrome 2, CAMRQ2, OMIM \#610185), has also been ascertained with homozygous WDR81 variants in two consanguineous families (-Table 2 , 
Novel Homozygous Frameshift WDR81 Mutation Kalmár et al.

Table 1 Reported compound heterozygous WDR81 variants causing alterations in isoform 1 of the WDR81 protein

\begin{tabular}{|c|c|c|c|c|c|c|c|c|}
\hline & Gender & Ethnicity & Location & $\begin{array}{l}\text { Nucleotide } \\
\text { variation }\end{array}$ & $\begin{array}{l}\text { Protein } \\
\text { variation }\end{array}$ & $\begin{array}{l}\text { Mutation } \\
\text { type }\end{array}$ & Phenotype & References \\
\hline 1 & $M$ & Caucasian & $\begin{array}{l}\text { Exon } 1 \\
\text { Exon } 2\end{array}$ & $\begin{array}{l}\text { c. } 1882 C>T \\
\text { c. } 3713 C>G\end{array}$ & $\begin{array}{l}\text { p.GIn628Ter } \\
\text { p.Pro1238Arg }\end{array}$ & $\begin{array}{l}\text { Nonsense } \\
\text { Missense }\end{array}$ & $\begin{array}{l}\text { Lissencephaly, extremely reduced } \\
\text { gyration, thin corpus callosum, } \\
\text { dysmyelination, normal cerebellum, } \\
\text { enlarged ventricles, and subarachnoid } \\
\text { space } \\
\text { No development, spastic tetraplegia, } \\
\text { generalized dyskinesia, nystagmus }\end{array}$ & 7 \\
\hline 2 & $F$ (fetus) & Caucasian & $\begin{array}{l}\text { Exon } 1 \\
\text { Exon } 9\end{array}$ & $\begin{array}{l}\text { c. } 2834 \_2837 \\
\text { delTGTT } \\
\text { c. } 5464 C>T\end{array}$ & $\begin{array}{l}\text { p.Phe946Serfs } \\
\text { Ter17 } \\
\text { p.Arg1822Ter }\end{array}$ & $\begin{array}{l}\text { Frameshift } \\
\text { Nonsense }\end{array}$ & $\begin{array}{l}\text { Delayed primary gyration, corpus } \\
\text { callosum agenesis, severe hypoplasia } \\
\text { of the brainstem and cerebellum }\end{array}$ & 7 \\
\hline 3 & $\mathrm{~F}$ & Caucasian & $\begin{array}{l}\text { Exon } 1 \\
\text { Exon } 4\end{array}$ & $\begin{array}{l}\text { c. } 1582 C>T \\
\text { c. } 4036 \_4041 \text { dup }\end{array}$ & $\begin{array}{l}\text { p.His528Tyr } \\
\text { p.Val1346_Thr } \\
\text { 1347dup }\end{array}$ & $\begin{array}{l}\text { Missense } \\
\text { Inframe } \\
\text { duplication }\end{array}$ & $\begin{array}{l}\text { Gyral simplification, thin corpus } \\
\text { callosum, cerebellar atrophy, } \\
\text { periventricular gliosis } \\
\text { No development, spastic tetraplegia, } \\
\text { generalized dyskinesia, nystagmus }\end{array}$ & 7 \\
\hline 4 & $\begin{array}{l}\mathrm{M}(+\mathrm{tw} \text { o } \mathrm{F} \\
\text { fetus } \\
\text { siblings })\end{array}$ & Caucasian & $\begin{array}{l}\text { Exon } 1 \\
\text { Exon } 1\end{array}$ & $\begin{array}{l}\text { c. } 1735 G>A \\
\text { c. } 1358 \text { dup }\end{array}$ & $\begin{array}{l}\text { p.Gly579Arg } \\
\text { p.Tyr453Ter }\end{array}$ & $\begin{array}{l}\text { Missense } \\
\text { Nonsense }\end{array}$ & $\begin{array}{l}\text { Lissencephaly, extremely reduced } \\
\text { gyration, thin corpus callosum, normal } \\
\text { cerebellum, dysmyelination, enlarged } \\
\text { ventricles and subarachnoid space } \\
\text { No development, spastic tetraplegia, } \\
\text { infantile spasms, dystonia, nystagmus }\end{array}$ & 7 \\
\hline 5 & $\mathrm{~F}$ & Caucasian & $\begin{array}{l}\text { Exon } 3 \\
\text { Exon } 9\end{array}$ & $\begin{array}{l}\text { c.3820_3835del } \\
\text { c.5453G > T }\end{array}$ & $\begin{array}{l}\text { p.Pro1274Thr } \\
\text { fsTer56 } \\
\text { p.Gly1818Val }\end{array}$ & $\begin{array}{l}\text { Frameshift } \\
\text { Missense }\end{array}$ & $\begin{array}{l}\text { Cortical atrophy, thin corpus callosum, } \\
\text { cerebellar atrophy, dysmyelination } \\
\text { No development, spastic tetraplegia, } \\
\text { epilepsy }\end{array}$ & 7 \\
\hline 6 & $\mathrm{~F}$ & NA & $\begin{array}{l}\text { Exon } 1 \\
\text { Exon } 1\end{array}$ & $\begin{array}{l}\text { c. } 84 G>A \\
\text { c. } 1855 C>T\end{array}$ & $\begin{array}{l}\text { p.Trp28Ter } \\
\text { P.Arg619Ter }\end{array}$ & $\begin{array}{l}\text { Nonsense } \\
\text { Nonsense }\end{array}$ & $\begin{array}{l}\text { Microcephaly, extremely simplified } \\
\text { gyral pattern, thin brain tissue, } \\
\text { pontocerebellar hypoplasia, corpus } \\
\text { callosum agenesis } \\
\text { Neonatal seizures, no development }\end{array}$ & 8 \\
\hline
\end{tabular}

Abbreviations: F, female; M, male; NA, not available.

Table 2 Reported homozygous WDR81 variants causing alterations in isoform 1 of the WDR81 protein

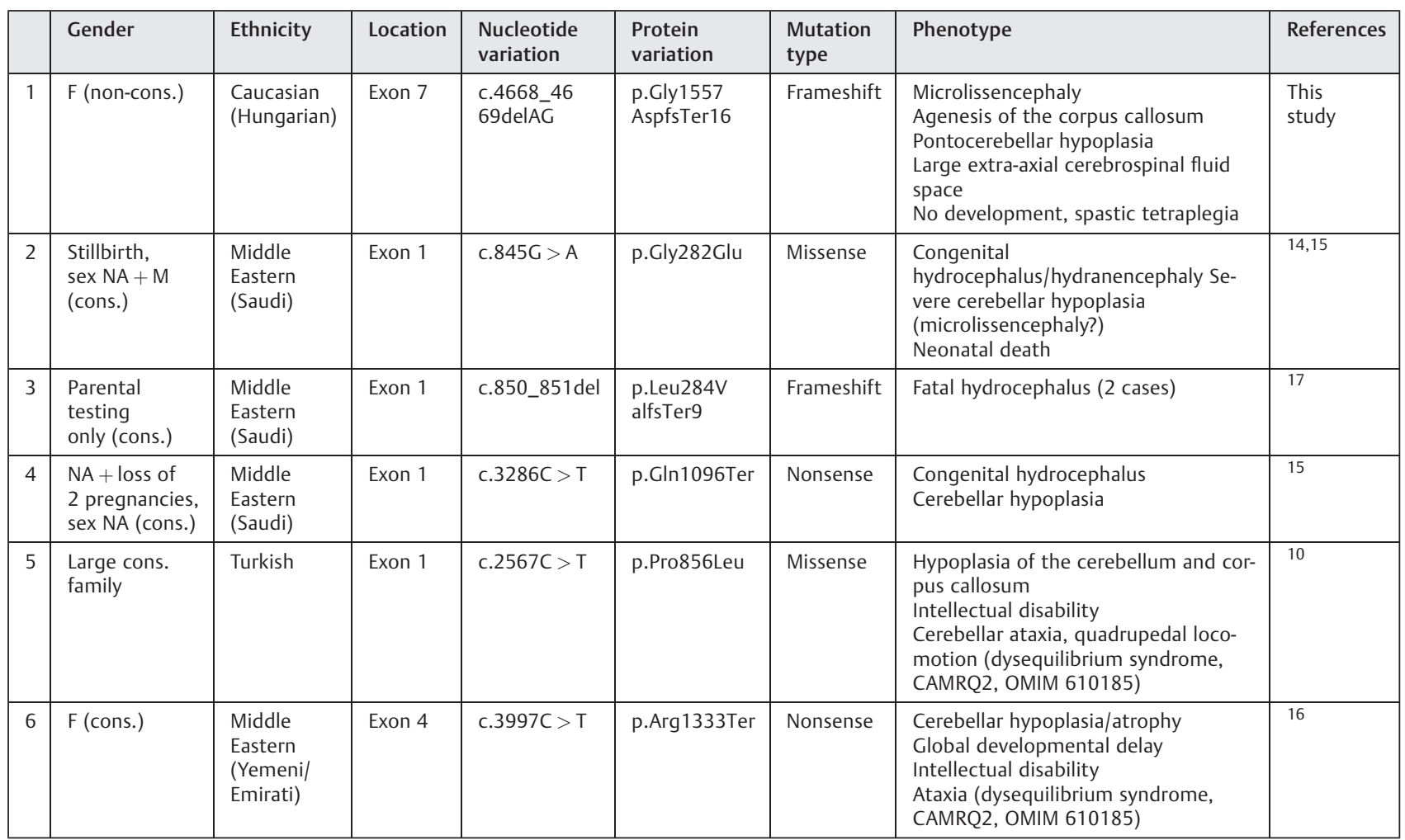

Abbreviations: cons., consanguinity; F, female; M, male, NA, not available. 
Patients 5 and 6). ${ }^{10,16}$ Phenotypic similarities to the latter condition were described in mice with missense mutation in the Wdr81 gene. ${ }^{18}$

Thus, in nonconsanguineous families, compound heterozygous, while in consanguineous families, homozygous mutations in WDR81 have been reported until now (-Tables 1 and 2). Remarkably, there is no evidence of a relationship between the parents of our patients, yet their offspring(s) had a homozygous mutation (-Table 2). The brain malformation spectrum in our patients was more severe than the microlissencephaly/microcephaly spectrum described in the nonconsanguineous patients with compound heterozygous mutations. ${ }^{7}$ It was comparable to the consanguineous patients with homozygous mutations and hydranencephaly/congenital hydrocephalus. ${ }^{14,15,17}$ Further studies are required to reveal how common this variant is in the Hungarian population and whether any founder effect exists.

WDR81 is a poorly characterized gene and the function of the encoded protein is still unclear. Isoforms 1 to 4 of the protein have been detected in all central nervous system regions in adult wild-type mice ${ }^{18}$; however, the function of these isoforms remains unknown. Particularly no information is available whether any of the isoforms would be able to compensate for the role of mutant isoform 1 . Recently, it has been suggested that WDR81 and WDR91 may have roles in endosomal function, ${ }^{19,20}$ or autophagy-dependent clearance of ubiquitinated and aggregated proteins. ${ }^{11}$ New research efforts might shed light on how WDR81 is involved in neurogenic cell divisions and cell fate regulations.

\section{Ethical Approval}

Written informed parental consent had been obtained. The study was approved by the Human Investigation Review Board at Albert Szent-Györgyi Clinical Centre, University of Szeged, Hungary.

\section{Funding}

This study was supported by the GINOP-2.3.2-15-2 grant (to T.K. and Z.M.) provided by the National Research, Development and Innovation Office (Hungary).

\section{Conflict of Interest}

None declared.

\section{Acknowledgment}

We thank the members of the patients' families for their cooperation.

\section{References}

1 Barkovich AJ, Ferriero DM, Barr RM, et al. Microlissencephaly: a heterogeneous malformation of cortical development. Neuropediatrics 1998;29(03):113-119
2 Alkuraya FS, Cai X, Emery C, et al. Human mutations in NDE1 cause extreme microcephaly with lissencephaly [corrected]. Am J Hum Genet 2011;88(05):536-547

3 Fallet-Bianco C, Laquerrière A, Poirier K, et al. Mutations in tubulin genes are frequent causes of various foetal malformations of cortical development including microlissencephaly. Acta Neuropathol Commun 2014;2:69

4 Hu WF, Pomp O, Ben-Omran T, et al. Katanin p80 regulates human cortical development by limiting centriole and cilia number. Neuron 2014;84(06):1240-1257

5 Harding BN, Moccia A, Drunat S, et al. Mutations in citron kinase cause recessive microlissencephaly with multinucleated neurons. Am J Hum Genet 2016;99(02):511-520

6 Poirier K, Martinovic J, Laquerrière A, et al. Rare ACTG1 variants in fetal microlissencephaly. Eur J Med Genet 2015;58(08):416-418

7 Cavallin M, Rujano MA, Bednarek N, et al. WDR81 mutations cause extreme microcephaly and impair mitotic progression in human fibroblasts and Drosophila neural stem cells. Brain 2017;140(10): 2597-2609

8 Cappuccio G, Pinelli M, Torella A, et al. An extremely severe phenotype attributed to WDR81 nonsense mutations. Ann Neurol 2017;82:650-651 (Correction). Ann Neurol 2018;84:796

9 Schwarz JM, Cooper DN, Schuelke M, Seelow D. MutationTaster2: mutation prediction for the deep-sequencing age. Nat Methods 2014;11(04):361-362

10 Gulsuner S, Tekinay AB, Doerschner K, et al. Homozygosity mapping and targeted genomic sequencing reveal the gene responsible for cerebellar hypoplasia and quadrupedal locomotion in a consanguineous kindred. Genome Res 2011;21(12):1995-2003

11 Liu X, Li Y, Wang X, et al. The BEACH-containing protein WDR81 coordinates p62 and LC3C to promote aggrephagy. J Cell Biol 2017;216(05):1301-1320

12 Shohayeb B, Lim NR, Ho U, et al. The role of WD40-repeat protein $62(\mathrm{MCPH} 2)$ in brain growth: diverse molecular and cellular mechanisms required for cortical development. Mol Neurobiol 2018;55(07):5409-5424

13 Stirnimann CU, Petsalaki E, Russell RB, Müller CW. WD40 proteins propel cellular networks. Trends Biochem Sci 2010;35(10):565-574

14 Alazami AM, Patel N, Shamseldin HE, et al. Accelerating novel candidate gene discovery in neurogenetic disorders via wholeexome sequencing of prescreened multiplex consanguineous families. Cell Reports 2015;10(02):148-161

15 Shaheen R, Sebai MA, Patel N, et al. The genetic landscape of familial congenital hydrocephalus. Ann Neurol 2017;81(06): 890-897

16 Komara M, John A, Suleiman J, Ali BR, Al-Gazali L. Clinical and molecular delineation of dysequilibrium syndrome type 2 and profound sensorineural hearing loss in an inbred Arab family. Am J Med Genet A 2016;170A(02):540-543

17 Maddirevula S, Alzahrani F, Al-Owain M, et al. Autozygome and high throughput confirmation of disease genes candidacy. Genet Med 2019;21(03):736-742

18 Traka M, Millen KJ, Collins D, et al. WDR81 is necessary for purkinje and photoreceptor cell survival. J Neurosci 2013;33 (16):6834-6844

19 Liu K, Jian Y, Sun X, et al. Negative regulation of phosphatidylinositol 3-phosphate levels in early-to-late endosome conversion. J Cell Biol 2016;212(02):181-198

20 Rapiteanu R, Davis LJ, Williamson JC, Timms RT, Paul Luzio J, Lehner PJ. A genetic screen identifies a critical role for the WDR81-WDR91 complex in the trafficking and degradation of tetherin. Traffic 2016;17(08):940-958 